\title{
A Dynamic Performance Evaluation Model for SMEs Based on Fuzzy DEMATEL and Fuzzy ANP
}

Merve Cengiz Toklu, Sakarya University, Serdivan / Sakarya, Turkey

Harun Taşkın, Sakarya University, Serdivan / Sakarya, Turkey

\begin{abstract}
Performance evaluation is a systematic way for companies to analyze their current status and progress to reach their goals. Companies constantly evaluate their processes in research and development, purchasing, production, sales and marketing departments in order to determine new ways to improve their capabilities. In this study, the authors proposed an evaluation model to evaluate the performance of small and medium enterprises (SME) which play a major role in country's economy under given high attention to "Production Process." In the proposed model, Fuzzy Decision Making Trial and Evaluation Laboratory (F-DEMATEL) and Fuzzy Analytic Network Process (F-ANP) methods were used to calculate the weights of performance criteria. A case study has been conducted in a manufacturing SME for empirical evidence. The results from this study indicate that C5.1 (new processes on the current or new products are developed and applied expeditiously), C3.3 (products are delivered on time) and C5.3 (products are appropriate to environment, health, safety and regulatory policies) are the most important criteria for the company to which the model was applied. "C5 Process Management" and "C3 Production Planning" are declared as two important main criteria relevance to others.
\end{abstract}

\section{KEYWORDS}

Fuzzy ANP, Fuzzy DEMATEL Performance Evaluation, Production Process, Small-Medium Enterprise

\section{INTRODUCTION}

Manufacturing industry has an important role for the economic development of countries due to the empirical correlation between the degree of industrialization and income per capita (Herman, 2011). Therefore, manufacturing companies should evaluate their performance periodically thereby to determine their targets and develop appropriate action plans for new ways to increase their capabilities. Performance measurement has a crucial role to sustain, efficient and effective management for manufacturing companies and is a part of continuous improvement (Susilawati, Tan, Bell, \& Sarwar, 2013). As typical, large companies have enough resources to measure their performance progress. However, small companies often either do not have sufficient understanding of or access to the resources, technologies, and management practices needed to meet these challenges (Walden, 2007). Therefore, solutions for SMEs diverse from the solutions for large companies.

In the literature, Multi-Criteria Decision Making (MCDM) techniques provide a wide range of solutions including activities such as selection, ranking and grouping. These techniques have been applied in different problems of the practitioners such as supplier selection, ranking of risk factors, renewable energy sources selection, etc. However, there are few studies that prioritize performance 
criteria with MCDM techniques for performance evaluation models in the literature. The aim of this study is to propose a dynamic, flexible and practicable performance evaluation model for production processes of SMEs. The model consists of several performance criteria and sub criteria for companies to achieve their objectives that range from operational to strategic levels. Moreover, the proposed model allows companies to adjust the set of criteria regards to their objectives. Therefore, the companies can include additional criteria as well as retrieving the redundant ones. In this way, companies can prioritize performance criteria according to their own priorities and they can utilize the model in order to achieve their strategic objectives.

The contribution of the proposed model into the literature can be summarized as follows;

- The model is flexible to increase the number of criteria in the criteria set respect to the needs of the companies.

- The model can be synchronously updated while the company's policy is revised.

- The model considers the limited resources of small companies and weaknesses of the other models in literature such as; tendency to bureaucracy, same specific performance criteria setting, requirement of more human resources, time and money.

- More importantly, the model enables decision makers to adjust the weights of the performance criteria respect to their priorities in order to achieve their goals.

In brief, the power of the model is due to its dynamic nature which let companies to adjust their performance criteria regards to their strategic plan. Additionally, criteria weights which are determined by MCDM techniques can also be modified and updated respect to the companies needs to become more competitive in the market. For instance, once the company aims to improve its manufacturing technology in a certain period of time, investing in new technologies or automation systems may be alternative approach for the company. Therefore, the criteria "the degree of automation" should highly be weighted comparing to other criteria.

This study includes six main sections. The first section focuses on the aim and the contribution of the study. Section 2 discusses the performance measurement models in the literature. The proposed model is presented in Section 3. Section 4 articulates the MCDM techniques used in the study. The application of the proposed model for an SME is represented in Section 5 by a case study. The last section concludes with the results of the case study and discusses the possible extensions of the study.

\section{LITERATURE REVIEW}

In traditional performance measurement systems used in the 1970s, more quantitative (financial) indicators such as "profitability" and "growth" are used to evaluate the performance of companies. Due to inadequacy of the traditional measurement models, Cross and Lynch developed the strategic measurement analysis and reporting technique which is also known as the performance pyramid. The performance pyramid is built on four levels and shows the links between corporate strategy, strategic business units and operations (Garengo et al., 2005). Performance Measurement Matrix (Keegan, Eiler, \& Jones, 1989) is one of the first models to stand out with its flexible and simple application. The hierarchical and integrated approach of performance measurement matrix allows defining strategic objectives and relating performance measures. The Balanced Scorecard which was developed by Kaplan and Norton (Kaplan \& Norton, 1996) is the most popular performance measurement model in both literature and practice. Balanced Scorecard model is used not only in the manufacturing sector but also in the service sector. For instance, Nisha (2017), investigated a study about how the balanced scorecard is used for performance evaluation in the banking sector of Bangladesh.

The model includes four main components: financial, customer, internal functions and learning and growth. The challenge of Balanced Scorecard is the need for external expert for criteria selection 
(Andersen, Lawrie, \& Shulver, 2000). Organizational Performance Measurement (Chennell et al., 2000) developed specifically for SMEs and has three principles: alignment, process thinking, and practicability. Integrated Dynamic Performance Measurement System, Quantitative models for performance measurement system and Performance prism are the other alternative performance measurement models. Lee et al. (Lee, Ryu, \& McKone-Sweet, 2013) aimed to tests a framework that identifies and relationships among IT resources, complementary resources to e-supply chains, and performance of a firm.

Presented models for the performance evaluation have strengths and weaknesses. Table 1 shows the brief summary of strengths and weaknesses of various frameworks. For instance, relations among the different indicators can be understood in performance pyramid system nevertheless it does not integrate the concept of continuous improvements. Most of the models are developed for large companies which have sufficient number of qualified human resources. Organizational Performance Measurement model is specifically developed for SMEs but objectives are not clearly defined in this model. The intent of this study is to propose a performance evaluation model considering the limited resources of SMEs in order to overcome the weaknesses of existing models in literature in terms of tendency to bureaucracy, fixed number of evaluation criteria, requirement to more human, money and time resource.

\section{PROPOSED MODEL}

The proposed model has four main steps as depicted in Figure 1. The first step of the model is to define strategic goals and objectives for the company. Second step is about creating the criteria set to reach strategic goals and objectives upon decision makers' view. In the case study, we consider decision makers as the senior executives of research \& development, purchasing and production departments of the company. At this juncture, companies can include specific criteria respect to their own goals and objectives or exclude some of the criteria which do not match with their objectives. The model is flexible to be applied for different companies and industries.

The third step includes mathematical operations to decide the criterion priorities. In this step, interactions between performance criteria are determined by F-DEMATEL method. F-ANP technique is used to prioritize criteria (Figure 2).

In the final step, the performance of the company is assessed and action plans are developed to enhance new developing directions for the companies. Once the strategic decisions are updated, regarding performance criteria are adjusted for the continuous improvement perspective.

\section{METHODOLOGY}

In the proposed model, two different MCDM methods are used. Firstly; F-DEMATEL method is used to analyze the relationships between performance criteria. Following, the weights of these performance criteria are determined by F-ANP method.

\section{The Fuzzy DEMATEL Method}

The DEMATEL method was introduced by Geneva Research Centre (Gabus \& Fontela, 1972, 1973). Lin and Wu (Lin \& Wu, 2008) extent the model to include fuzzy logic and defined the new method as F-DEMATEL. The linguistic terms and their corresponding triangular fuzzy numbers which are used to pairwise comparisons in F-DEMATEL method are shown in Table 2.

The major steps of the F-DEMATEL method were explained as the following;

Obtaining the assessments of all decision-makers; 
Table 1. Strengths and weaknesses of various framework

\begin{tabular}{|c|c|c|}
\hline Model (Author, year) & Strengths & Weaknesses \\
\hline $\begin{array}{l}\text { Performance Pyramid System } \\
\text { (Cross \& Lynch, 1988) }\end{array}$ & $\begin{array}{l}\text { Structured on levels, thus the relations } \\
\text { among the different indicators can be } \\
\text { understood (Chalmeta, Palomero, \& } \\
\text { Matilla, 2012). }\end{array}$ & $\begin{array}{l}\text { It does not integrate concept of continuous } \\
\text { improvements (Yadav \& Sagar, 2013) }\end{array}$ \\
\hline $\begin{array}{l}\text { Malcolm Baldrige National } \\
\text { Quality Award (Malcolm } \\
\text { Baldrige Performance } \\
\text { Excellence Program, 1989) }\end{array}$ & Customer oriented (Nguyen, 2010) & $\begin{array}{l}\text { MBNQA requires documentation for all } \\
\text { process for this reason may not be adopted } \\
\text { by SMEs }\end{array}$ \\
\hline $\begin{array}{l}\text { Performance Measurement } \\
\text { Matrix (Keegan et al., 1989) }\end{array}$ & $\begin{array}{l}\text { Simple and flexible application. } \\
\text { Integrated approach and strategic } \\
\text { alignment (Chalmeta et al., 2012). }\end{array}$ & $\begin{array}{l}\text { Lack of different points of view and } \\
\text { relations between objectives and indicators } \\
\text { (Chalmeta et al., 2012). }\end{array}$ \\
\hline $\begin{array}{l}\text { EFQM (The EFQM } \\
\text { Excellence Model, 1991) }\end{array}$ & $\begin{array}{l}\text { Strengthen the sense of quality and } \\
\text { creating conditions for comparative } \\
\text { analysis of business processes with } \\
\text { external business (Striteska \& Spickova, } \\
\text { 2012) }\end{array}$ & $\begin{array}{l}\text { Criteria are not specific within the } \\
\text { company. no possibility for differentiation } \\
\text { and tendency to bureaucracy (Striteska \& } \\
\text { Spickova, 2012) }\end{array}$ \\
\hline $\begin{array}{l}\text { Balanced Scorecard (Kaplan } \\
\text { \& Norton, 1996) }\end{array}$ & $\begin{array}{l}\text { The most widely known model based } \\
\text { on four easily identifiable perspectives } \\
\text { (Chalmeta et al., 2012) }\end{array}$ & $\begin{array}{l}\text { Cannot view the performance at } \\
\text { manufacturing level (Susilawati et al., } \\
\text { 2013) } \\
\text { Customers are not directly involved in the } \\
\text { process (Garengo et al., 2005) }\end{array}$ \\
\hline $\begin{array}{l}\text { Integrated Performance } \\
\text { Meas. (U.S. Bititci, Carrie, \& } \\
\text { McDevitt, 1997) }\end{array}$ & $\begin{array}{l}\text { Strengthen to involve the continuous } \\
\text { improvement (Susilawati et al., 2013) }\end{array}$ & $\begin{array}{l}\text { Unclear to measure in a logical order } \\
\text { and manage the relationships between } \\
\text { measures (Susilawati et al., 2013) }\end{array}$ \\
\hline $\begin{array}{l}\text { Integrated Dynamic } \\
\text { Performance Measurement } \\
\text { System (Ghalayini, Noble, \& } \\
\text { Crowe, 1997) }\end{array}$ & $\begin{array}{l}\text { It helps for dynamic updating of } \\
\text { general areas of success and associated } \\
\text { performance measures and indicators } \\
\text { (Yadav \& Sagar, 2013) }\end{array}$ & $\begin{array}{l}\text { It is extensively for manufacturing-based } \\
\text { companies and its generalized application } \\
\text { is not discussed (Yadav \& Sagar, 2013) }\end{array}$ \\
\hline $\begin{array}{l}\text { Organizational Performance } \\
\text { Measurement (Chennell et al., } \\
\text { 2000) }\end{array}$ & $\begin{array}{l}\text { Specifically developed for SMEs } \\
\text { (Taticchi et al., 2008) }\end{array}$ & $\begin{array}{l}\text { Objectives are not clearly defined } \\
\text { (Taticchi et al., 2008) }\end{array}$ \\
\hline $\begin{array}{l}\text { Quantitative models for } \\
\text { performance measurement } \\
\text { system (Suwignjo, Bititci, \& } \\
\text { Carrie, 2000) }\end{array}$ & $\begin{array}{l}\text { It allows the sensitivity of alternative } \\
\text { strategic choices to be evaluated } \\
\text { (Chalmeta et al., 2012) }\end{array}$ & $\begin{array}{l}\text { Requires specialized knowledge (Chalmeta } \\
\text { et al., 2012) }\end{array}$ \\
\hline $\begin{array}{l}\text { Kanji Business Excellence } \\
\text { Measurement System (Kanji, } \\
\text { 2002) }\end{array}$ & $\begin{array}{l}\text { It combines financial and non- financial } \\
\text { measures and the assessment of different } \\
\text { stakeholders (Striteska \& Spickova, } \\
\text { 2012) }\end{array}$ & $\begin{array}{l}\text { Primarily designed for senior managers } \\
\text { to provide them with an overall view of } \\
\text { performance (Striteska \& Spickova, 2012) }\end{array}$ \\
\hline $\begin{array}{l}\text { Performance prism (Neely, } \\
\text { Adams, \& Kennerley, 2002) }\end{array}$ & $\begin{array}{l}\text { It allows a strategic performance } \\
\text { measurement system and considers } \\
\text { whole stakeholders. (Chalmeta et al., } \\
\text { 2012; Striteska \& Spickova, 2012) }\end{array}$ & $\begin{array}{l}\text { The development of operational measures } \\
\text { is dealt with as an optional process } \\
\text { (Chalmeta et al., 2012). } \\
\text { Partially strategy alignment (Garengo et } \\
\text { al., 2005) }\end{array}$ \\
\hline $\begin{array}{l}\text { Measuring performance of } \\
\text { SMEs (Gin Chong, 2008) }\end{array}$ & $\begin{array}{l}\text { Valid and reliable model (Chalmeta et } \\
\text { al., 2012) }\end{array}$ & $\begin{array}{l}\text { Suggestions for implementation are } \\
\text { obtained rather than guidelines (Chalmeta } \\
\text { et al., 2012) }\end{array}$ \\
\hline
\end{tabular}


Figure 1. Framework of the proposed model

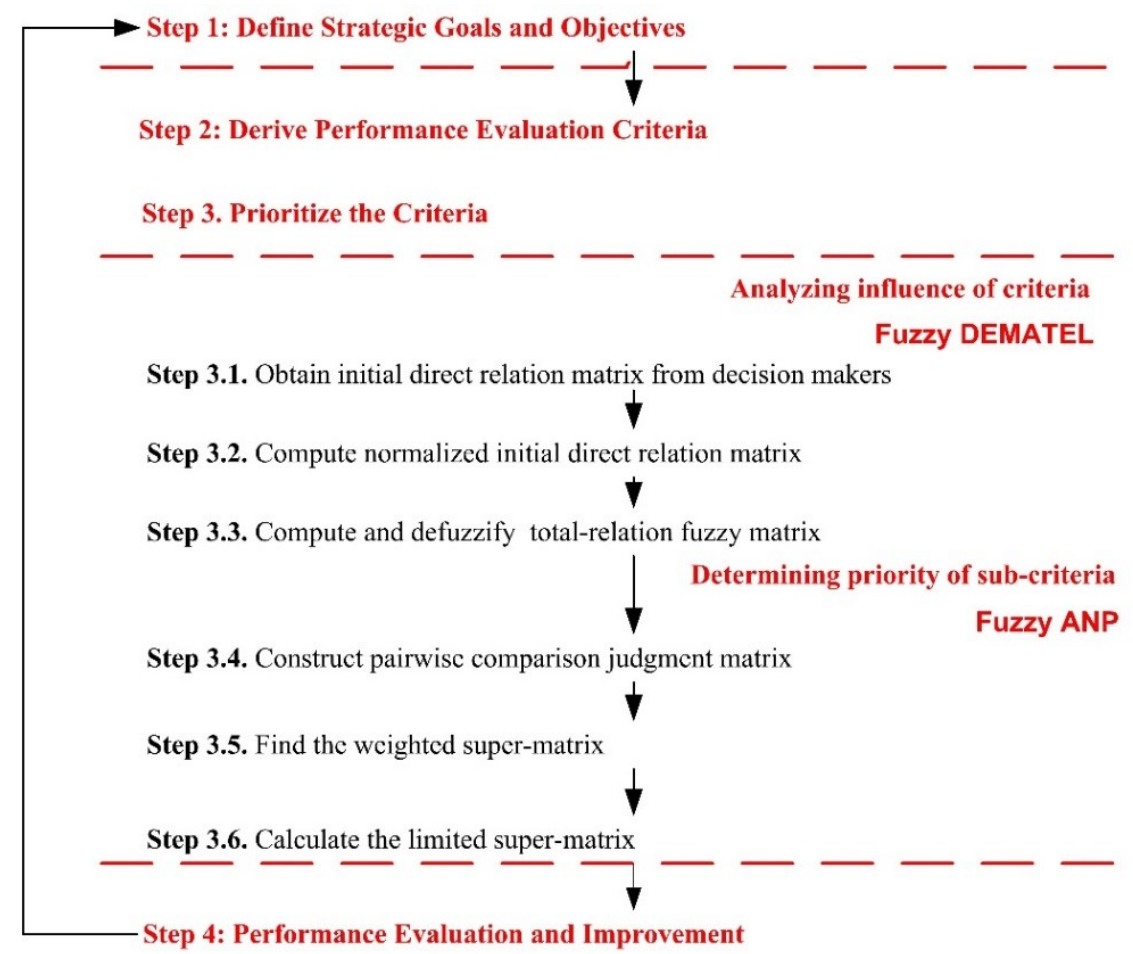

Figure 2. Prioritizing the performance criteria

Prioritization of Performance Criteria

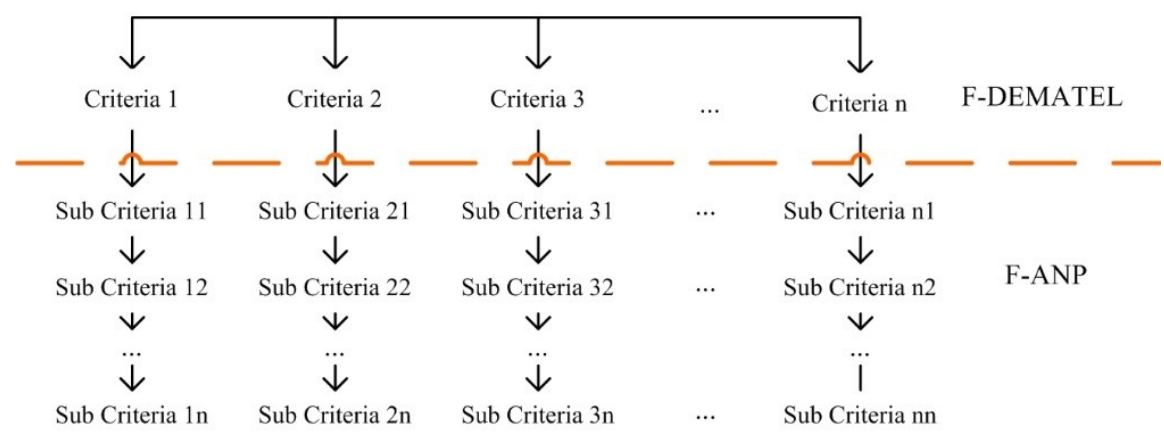


Table 2. The correspondence of linguistic terms and linguistic values

\begin{tabular}{|l|l|}
\hline Linguistic Terms & Linguistic Values \\
\hline No Influence & $(0,0,0.25)$ \\
\hline Very Low Influence & $(0,0.25,0.50)$ \\
\hline Low Influence & $(0.25,0.50,0.75)$ \\
\hline High Influence & $(0.50,0.75,1.0)$ \\
\hline Very High Influence & $(0.75,1.0,1.0)$ \\
\hline
\end{tabular}

$\tilde{Z}=\frac{\tilde{Z}_{1}+\tilde{Z}_{2}+\ldots+\tilde{Z}_{p}}{p}$

$\tilde{Z}($ initial direct relation fuzzy matrix $)$ :

$\tilde{Z}=\left[\begin{array}{cccc}0 & \tilde{z}_{12} & \cdots & \tilde{z}_{1 n} \\ \tilde{z}_{21} & 0 & \cdots & \tilde{z}_{2 n} \\ \vdots & \vdots & \ddots & \vdots \\ \tilde{z}_{n 1} & \tilde{z}_{n 2} & \cdots & 0\end{array}\right]$

$\tilde{X}$ (Normalized direct-relation fuzzy matrix):

$\tilde{X}=\left[\begin{array}{cccc}\tilde{x}_{11} & \tilde{x}_{12} & \cdots & \tilde{x}_{1 n} \\ \tilde{x}_{21} & \tilde{x}_{22} & \cdots & \tilde{x}_{2 n} \\ \vdots & \vdots & \ddots & \vdots \\ \tilde{x}_{n 1} & \tilde{x}_{n 2} & \cdots & \tilde{x}_{n n}\end{array}\right]$

where $\tilde{x}_{i j}=\frac{\tilde{z}_{i j}}{r}=\left(\frac{\ell_{i j}}{r}, \frac{m_{i j}}{r}, \frac{u_{i j}}{r}\right)$

$r=\max _{1 \leq i \leq n}\left(\sum_{j=1}^{n} u_{i j}\right)$

Total-relation fuzzy matrix $(\tilde{T})$ : 


$$
\begin{aligned}
& X_{\ell}=\left[\begin{array}{cccc}
0 & \ell_{12}^{\prime} & \cdots & \ell_{1 n}^{\prime} \\
\ell_{21}^{\prime} & 0 & \cdots & \ell_{2 n}^{\prime} \\
\vdots & \vdots & \ddots & \vdots \\
\ell_{n 1}^{\prime} & \ell_{n 2}^{\prime} & \cdots & 0
\end{array}\right] \\
& X_{m}=\left[\begin{array}{cccc}
0 & m_{12}^{\prime} & \cdots & m_{1 n}^{\prime} \\
m_{21}^{\prime} & 0 & \cdots & m_{2 n}^{\prime} \\
\vdots & \vdots & \ddots & \vdots \\
m_{n 1}^{\prime} & m_{n 2}^{\prime} & \cdots & 0
\end{array}\right] \\
& X_{u}=\left[\begin{array}{cccc}
0 & u_{12}^{\prime} & \cdots & u_{1 n}^{\prime} \\
u_{21}^{\prime} & 0 & \cdots & u_{2 n}^{\prime} \\
\vdots & \vdots & \ddots & \vdots \\
u_{n 1}^{\prime} & u_{n 2}^{\prime} & \cdots & 0
\end{array}\right] \\
& \tilde{T}=\left[\begin{array}{cccc}
\tilde{t}_{11} & \tilde{t}_{12} & \cdots & \tilde{t}_{1 n} \\
\tilde{t}_{21} & \tilde{t}_{22} & \cdots & \tilde{t}_{2 n} \\
\vdots & \vdots & \ddots & \vdots \\
\tilde{t}_{n 1} & \tilde{t}_{n 2} & \cdots & \tilde{t}_{n n}
\end{array}\right] \text { where } \tilde{t}_{i j}=\left(\ell_{i j}^{\prime \prime}, m_{i j}^{\prime \prime}, u_{i j}^{\prime \prime}\right) \\
& {\left[\ell_{i j}^{\prime \prime}\right]=X_{\ell} \times\left(I-X_{\ell}\right)^{-1}} \\
& {\left[m_{i j}^{\prime \prime}\right]=X_{m} \times\left(I-X_{m}\right)^{-1}} \\
& {\left[u_{i j}^{\prime \prime}\right]=X_{u} \times\left(I-X_{u}\right)^{-1}}
\end{aligned}
$$

$\left(\tilde{D}_{i}+\tilde{R}_{i}\right)$ and $\left(\tilde{D}_{i}-\tilde{R}_{i}\right)$ values: $\tilde{D}_{i}$ and $\tilde{R}_{i}$ are the sum of rows and columns of defuzzified total-relation fuzzy matrix $\left(\tilde{\mathrm{T}}^{\text {def }}\right)$, respectively.

$$
\tilde{T}^{\text {def }}=\left[\begin{array}{cccc}
\tilde{t}_{11}{ }^{d e f} & \tilde{t}_{12}{ }^{d e f} & \cdots & \tilde{t}_{1 n}{ }^{d e f} \\
\tilde{t}_{21}{ }^{d e f} & \tilde{t}_{22}{ }^{d e f} & \cdots & \tilde{t}_{2 n}^{d e f} \\
\vdots & \vdots & \ddots & \vdots \\
\tilde{t}_{n 1}{ }^{d e f} & \tilde{t}_{n 2}{ }^{d e f} & \cdots & \tilde{t}_{n n}^{d e f}
\end{array}\right]
$$

Where $\tilde{t}_{i j}^{\text {def }}=\left(\ell_{i j}^{\prime \prime}, m_{i j}^{\prime \prime}, u_{i j}^{\prime \prime}\right)^{d e f}$ 
After these steps defuzzification process is applied. Defuzzification is the conversion of a fuzzy quantity to a precise quantity, just as fuzzification is the conversion of a precise quantity to a fuzzy quantity (Ross, 2004). In the proposed model, Converting Fuzzy Data Into Crisp Scores (CFCS) defuzzification method (Opricovic \& Tzeng, 2003) is used.

\section{The Fuzzy ANP Method}

The ANP method is a general form of the analytic hierarchy process (AHP). ANP method eliminates the problem of interrelation among criteria (Saaty, 1996). Dependency relationships are obtained from F-DEMATEL method. Criteria weights are determined by using the F-ANP method regards to the relationships among each other. There are different fuzzy forms of ANP in the literature. In this study, we used Chang's extent analysis method (Chang, 1996). The linguistic terms and their corresponding triangular fuzzy numbers are shown in Table 3.

Chang's extent analysis method is described below.

Let $X=\left\{x_{1}, x_{2}, \ldots, x_{n}\right\}$ be an object set, and $G=\left\{g_{1}, g_{2}, \ldots, g_{m}\right\}$ be a goal set. $M_{g_{i}}^{1}, M_{g_{i}}^{2}, \ldots, M_{g_{i}}^{m}, \quad i=1,2, \ldots, n$ where all the $M_{g_{i}}^{j}(j=1,2, \ldots, m)$ are triangular fuzzy numbers.

The value of fuzzy synthetic extent with respect to the $i$ th object is defined as

$$
\mathrm{S}_{\mathrm{i}}=\sum_{\mathrm{j}}^{\mathrm{m}} \mathrm{M}_{\mathrm{g}_{\mathrm{i}}}^{\mathrm{j}} \otimes\left[\sum_{\mathrm{i}=1}^{\mathrm{n}} \sum_{\mathrm{j}=1}^{\mathrm{m}} \mathrm{M}_{\mathrm{g}_{\mathrm{i}}}^{\mathrm{j}}\right]^{-1}
$$

To obtain $\sum_{j}^{m} M_{g_{i}}^{j}$, perform the fuzzy addition operation of $m$ extent analysis values for a particular matrix such that;

$$
\sum_{j}^{m} M_{g_{i}}^{j}=\left(\sum_{j=1}^{m} l_{j}, \sum_{j=1}^{m} m_{j}, \sum_{j=1}^{m} u_{j}\right)
$$

To obtain $\left[\sum_{i=1}^{n} \sum_{j=1}^{m} M_{g_{i}}^{j}\right]^{-1}$, perform the fuzzy addition operation of $M_{g_{i}}^{j}(j=1,2, \ldots, m)$ values such that;

Table 3. The triangular fuzzy numbers and linguistic variables

\begin{tabular}{|l|l|l|}
\hline \multicolumn{1}{|c|}{ Linguistic variables } & \multicolumn{1}{|c|}{ Triangular fuzzy numbers } & \multicolumn{1}{c|}{$\begin{array}{c}\text { Triangular fuzzy reciprocal } \\
\text { numbers }\end{array}$} \\
\hline Equally Important & $(1,1,1)$ & $(1,1,1)$ \\
\hline Weekly Important & $(1,3,5)$ & $(1 / 5,1 / 3,1)$ \\
\hline Strongly Important & $(3,5,7)$ & $(1 / 7,1 / 5,1 / 3)$ \\
\hline Very Important & $(5,7,9)$ & $(1 / 9,1 / 7,1 / 5)$ \\
\hline Absolutely Important & $(7,9,9)$ & $(1 / 9,1 / 9,1 / 7)$ \\
\hline
\end{tabular}


$\sum_{i=1}^{n} \sum_{j=1}^{m} M_{g_{i}}^{j}=\left(\sum_{i=1}^{n} l_{i}, \sum_{i=1}^{n} m_{i}, \sum_{i=1}^{n} u_{i}\right)$

$\left[\sum_{i=1}^{n} \sum_{j=1}^{m} M_{g_{i}}^{j}\right]^{-1}=\left(\frac{1}{\sum_{i=1}^{n} u_{i}}, \frac{1}{\sum_{i=1}^{n} m_{i}}, \frac{1}{\sum_{i=1}^{n} l_{i}}\right)$

$M_{2}=\left(l_{2}, m_{2}, u_{2}\right) \geq M_{1}=\left(l_{1}, m_{1}, u_{1}\right)$ is defined as

$V\left(M_{2} \geq M_{1}\right)=\sup \left[\min \left(\mu_{M_{1}}(x), \mu_{M_{2}}(y)\right)\right]$ and can be equivalently expressed as follows:

$V\left(M_{2} \geq M_{1}\right)=\operatorname{hgt}\left(M_{1} \cap M_{2}\right)=$

$\mu_{M_{2}}(d)= \begin{cases}1, & \text { if } m_{2} \geq m_{1} \\ 0, & \text { if } l_{1} \geq u_{2} \\ \frac{l_{1}-u_{2}}{\left(m_{2}-u_{2}\right)-\left(m_{1}-l_{1}\right)}, & \text { otherwise }\end{cases}$

where $d$ is the ordinate of the highest intersection point $d$ between $\mu_{M_{1}}$ and $\mu_{M_{2}}$.

Both values of $V\left(M_{1} \geq M_{2}\right)$ and $V\left(M_{2} \geq M_{1}\right)$ are required in order to compare $M_{1}$ and $M_{2}$.

$V\left(M \geq M_{1}, M_{2}, \ldots, M_{k}\right)=V\left[\left(M \geq M_{1}\right)\right.$ and $\left(M \geq M_{2}\right)$ and $\ldots$ and $\left.\left(M \geq M_{k}\right)\right]$

$=\min V\left(M \geq M_{i}\right), \quad i=1,2, \ldots, k$

Assume that $d^{\prime}\left(A_{i}\right)=\min V\left(S_{i} \geq S_{k}\right)$ for $k=1,2, \ldots, n ; k \neq i$

$W^{\prime}=\left(d^{\prime}\left(A_{1}\right), d^{\prime}\left(A_{2}\right), \ldots, d^{\prime}\left(A_{n}\right)\right)^{T}$, where

$A_{i}(i=1,2, \ldots, n)$ are $n$ elements

$W=\left(d\left(A_{1}\right), d\left(A_{2}\right), \ldots, d\left(A_{n}\right)\right)^{T}$, where $W$ is a non-fuzzy number 


\section{CASE STUDY}

The proposed model was applied in a manufacturing SME. As a result of meetings with managerial staff, the production process is divided into five main evaluation parts which are production input, inventory management, production planning, manufacturing technology and process management.

The company announced the strategic goal as "achieve efficient and agile production process in order to manufacture high quality products by focusing on the technological improvement". Consequently, 5 objectives are defined to reach the strategic goal. These are;

- Delivery on time in customer needs while maintaining the same quality

- Efficient use of production resources

- Increase production capacity

- Modernization of existing production areas and sufficiency of technical equipment

- Integration of new processes into the current system without any quality problems.

A criterion set was established in the direction of the objectives and literature. Each main criterion has its own sub-criteria and there are 18 sub-criteria in total. The criteria set are given in Table 4. For instance, production flows, bill of materials, standard production times are classified as the production input. Likewise, inventory tracking system, safety stock levels are classified under inventory management.

Interactions between criteria are calculated with F-DEMATEL method by using Equation (1-6). The threshold value is determined as 0.560 by decision makers in the company. Values of criteria which are above the predefined threshold value are shown in the defuzzified total relation matrix in Table 5. For instance, Criteria 1 affects Criteria 2 (0.621) and Criteria $3(0.653)$ and also affected by Criteria $2(0.610)$.

After determination of the interactions, criteria weights are calculated with F-ANP method by using Equations (7-15). Figure 3 presents the criteria weights. The most important criteria are listed as C5.1 (New processes on the current or new products are developed and applied expeditiously), C3.3 (Products are delivered on time) and C5.3 (Products are appropriate to the environment, health, safety and regulatory policies).

The least important criteria are determined as C1.3 (All components are integrated with product serial code), C4.1 (Efficient use of raw materials techniques are used to reduce the shavings and scrap) and C5.2 (Total preventive maintenance is applied to reduce downtime as mentioned before). Since the importance of each criteria changes respect to the companies objectives, results does not state that criteria C1.3, C4.1 and C5.2 are not important for the other SMEs or vice versa.

Main criteria weights which are calculated based on sub-criteria weights are shown in Figure 4. Dimensions, "C5 Process Management" and "C3 Production Planning" are declared as more important than others. "C1 Production Input" and "C4 Manufacturing Technology" are declared as less important criteria.

In this case study, the focus of the company is on the production process. Manufacturing technology is important for big companies since they invest large amount of money to effectively use these technologies. On the other hand, SMEs may not able to invest on manufacturing technologies as much as large companies due to their limited resources.

\section{CONCLUSIONS}

This study suggests a hybrid MCDM approach to evaluate the performance of small and medium enterprises under given high attention to production process. A case study has been conducted in a manufacturing SME for empirical evidence. The model provides following advantages; 


\section{Table 4. Criteria and sub-criteria}

\begin{tabular}{|c|c|c|}
\hline Criteria & Ref. & Sub-Criteria \\
\hline \multirow{4}{*}{$\begin{array}{l}\text { C1 } \\
\text { Production } \\
\text { Input }\end{array}$} & \multirow{4}{*}{$\begin{array}{l}\text { (Genaidy \& Karwowski, 2007) } \\
\text { (Canvar Kahveci, 2007) } \\
\text { (Genaidy \& Karwowski, 2007) } \\
\text { (Susilawati et al., 2013) }\end{array}$} & C11: Bill of materials and production flows are up to date \\
\hline & & C12: Standard production times are determined \\
\hline & & $\begin{array}{l}\text { C13: All components are integrated with product serial } \\
\text { code }\end{array}$ \\
\hline & & C14: Set-up times are determined \\
\hline \multirow{4}{*}{$\begin{array}{l}\mathrm{C} 2 \\
\text { Inventory } \\
\text { Management }\end{array}$} & \multirow{4}{*}{$\begin{array}{l}\text { (Genaidy \& Karwowski, 2007) } \\
\text { (Genaidy \& Karwowski, 2007) } \\
\text { (Laitinen, 2002) }\end{array}$} & C21: Safety stock levels are available \\
\hline & & C22: Inventory tracking system is available \\
\hline & & $\begin{array}{l}\text { C23: The layout of the workshop provides efficient } \\
\text { material flow }\end{array}$ \\
\hline & & $\begin{array}{l}\text { C24: Inventory management for critical and spare parts is } \\
\text { carried out effectively }\end{array}$ \\
\hline \multirow{3}{*}{$\begin{array}{l}\text { C3 } \\
\text { Production } \\
\text { Planning }\end{array}$} & \multirow{3}{*}{$\begin{array}{l}\text { (Genaidy \& Karwowski, 2007) } \\
\text { (Genaidy \& Karwowski, 2007) } \\
\text { (Umit S. Bititci, 1996) } \\
\text { (Chalmeta et al., 2012) }\end{array}$} & C31: Annual production plan is available \\
\hline & & C32: Capacity planning is carried out \\
\hline & & C33: Products are delivered on time \\
\hline \multirow{4}{*}{$\begin{array}{l}\text { C4 } \\
\text { Manufacturing } \\
\text { Technology }\end{array}$} & \multirow{4}{*}{$\begin{array}{l}\text { (Genaidy \& Karwowski, 2007) } \\
\text { (Susilawati et al., 2013) } \\
\text { (Genaidy \& Karwowski, 2007) } \\
\text { (Chalmeta et al., 2012) } \\
\text { (Susilawati et al., 2013) } \\
\text { (Canvar Kahveci, 2007) } \\
\text { (Canvar Kahveci, 2007) } \\
\text { (Chalmeta et al., 2012) }\end{array}$} & $\begin{array}{l}\mathrm{C} 41 \text { : Efficient use of raw materials techniques are used to } \\
\text { reduce the shavings and scrap }\end{array}$ \\
\hline & & $\begin{array}{l}\text { C42: Degree of automation is high (AS-RS, robotic, } \\
\text { CNC, etc.) }\end{array}$ \\
\hline & & $\begin{array}{l}\text { C43: Latest technological innovations are used in } \\
\text { production process }\end{array}$ \\
\hline & & $\begin{array}{l}\text { C44: Existing technological structure is evaluated } \\
\text { periodically, and periodic renewal and maintenance is } \\
\text { done }\end{array}$ \\
\hline \multirow{3}{*}{$\begin{array}{l}\text { C5 } \\
\text { Process } \\
\text { Management }\end{array}$} & \multirow{3}{*}{$\begin{array}{l}\text { (Genaidy \& Karwowski, 2007) } \\
\text { (Walden, 2007) } \\
\text { (Genaidy \& Karwowski, 2007) } \\
\text { (Canvar Kahveci, 2007) } \\
\text { (Chalmeta et al., 2012) }\end{array}$} & $\begin{array}{l}\text { C51: New processes on the current or new products are } \\
\text { developed and applied expeditiously }\end{array}$ \\
\hline & & $\begin{array}{l}\text { C52: Total preventive maintenance is applied to reduce } \\
\text { downtime }\end{array}$ \\
\hline & & $\begin{array}{l}\text { C53: Products are appropriate to the environment, health, } \\
\text { safety and regulatory policies }\end{array}$ \\
\hline
\end{tabular}

Table 5. Defuzzified total relation matrix by using CFCS method

\begin{tabular}{|c|c|c|c|c|c|c|c|c|c|}
\hline Def & C1 & C2 & C3 & C4 & C5 & D & R & D + R & D -R \\
\hline C1 & 0.385 & $\mathbf{0 . 6 2 1}$ & $\mathbf{0 . 6 5 3}$ & 0.424 & 0.554 & 2.637 & 2.492 & 5.129 & 0.145 \\
\hline C 2 & $\mathbf{0 . 6 1 0}$ & 0.508 & $\mathbf{0 . 7 7 4}$ & $\mathbf{0 . 5 8 0}$ & $\mathbf{0 . 6 7 7}$ & 3.149 & 2.794 & 5.943 & 0.355 \\
\hline C3 & 0.476 & 0.517 & 0.475 & 0.452 & $\mathbf{0 . 5 7 7}$ & 2.497 & 3.276 & 5.772 & -0.779 \\
\hline C4 & 0.501 & 0.543 & $\mathbf{0 . 6 5 8}$ & 0.361 & $\mathbf{0 . 6 0 5}$ & $2.668 /$ & 2.309 & 4.977 & 0.359 \\
\hline C5 & 0.519 & $\mathbf{0 . 6 0 5}$ & $\mathbf{0 . 7 1 6}$ & 0.492 & 0.472 & 2.803 & 2.884 & 5.688 & -0.081 \\
\hline R & 2.492 & 2.794 & 3.276 & 2.309 & 2.884 & & & & \\
\hline
\end{tabular}

* threshold value: 0.560 
Figure 3. Sub-Criteria weights percentage

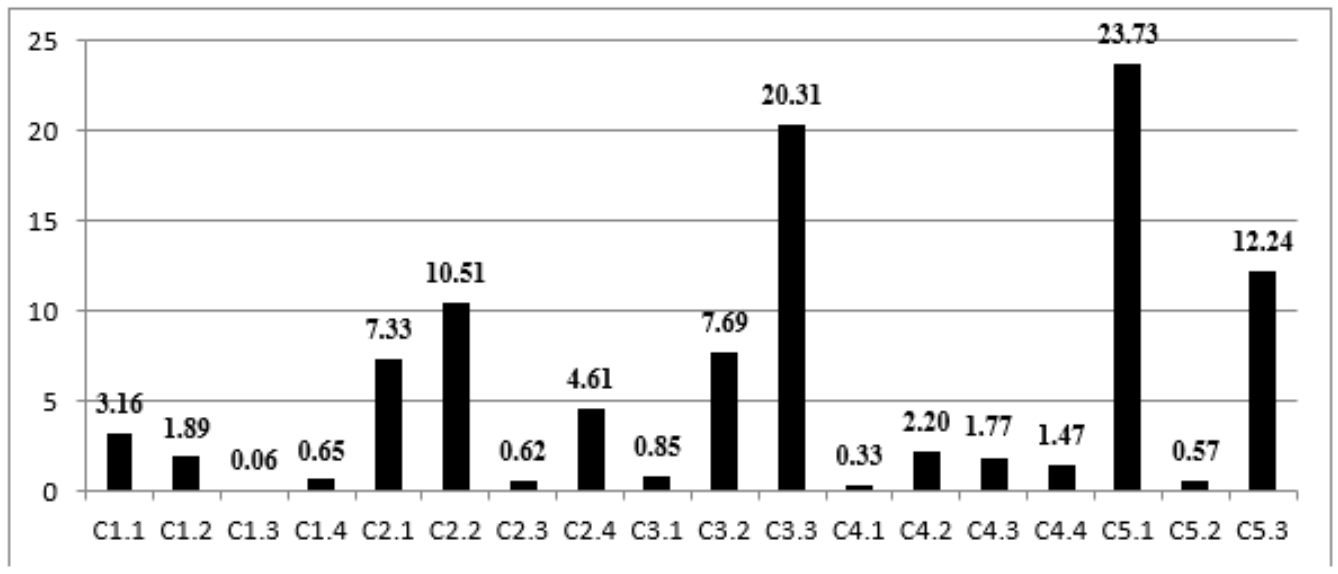

Figure 4. Main criteria weights percentage

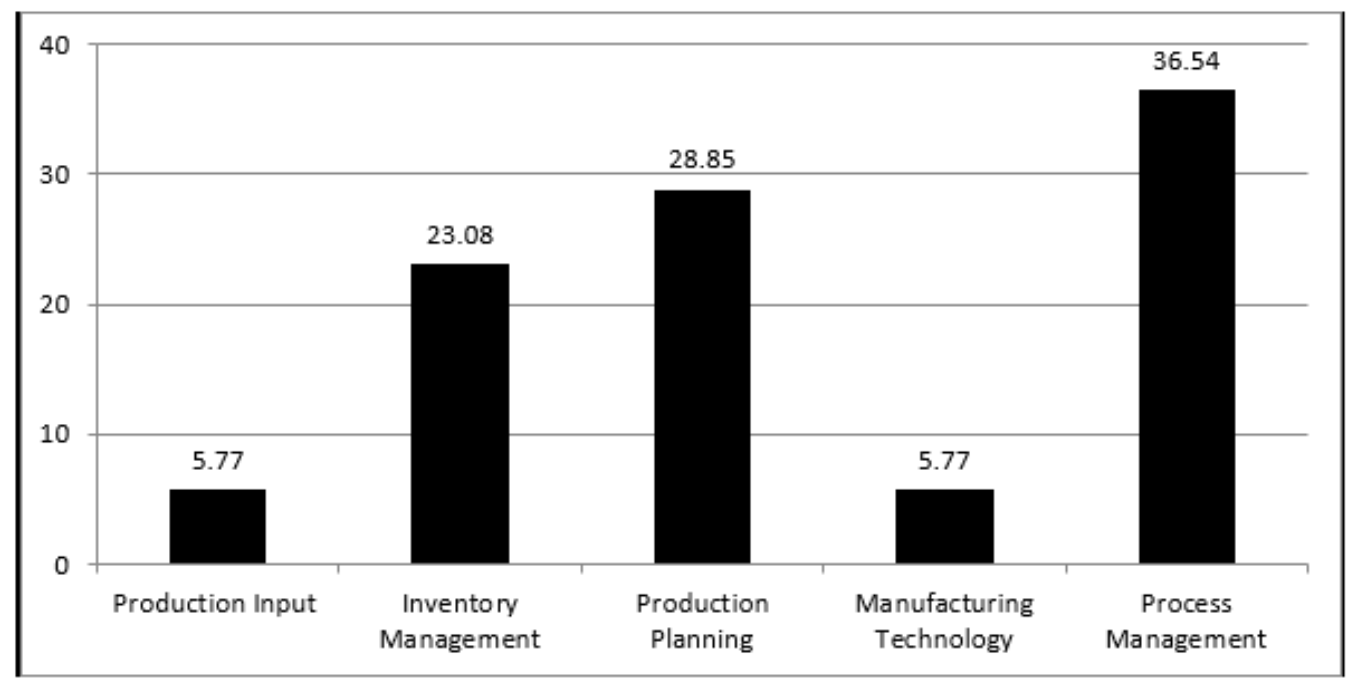

- In the proposed model, criteria weights are determined by MCDM techniques. Pairwise comparisons of criteria are made by decision makers. The performance criteria of the company were discussed in detail and the consensus was reached during the meetings where the decision makers met.

- Criteria set in the model can be tailored to the company needs. Therefore, the model can be applied into different companies and can be updated according to the company's strategy.

- The proposed model can be used for specific periods with the same criteria weights to track the performance the company.

In the model, criteria sets and criteria weights are adjusted regards to the needs of the company. Due to the difference in each company's strategic road map, performance criteria and criteria weights 
may vary one company to another. Business enterprises can improve their organizational performance by giving priority to activities related with the performance criteria.

Even the advantages presented above, the proposed model has some limitations. First, the increase in the number of criteria can be a time-consuming for decision makers due to the increased number of pairwise comparisons. Second, the change on the criteria set and their weights cause repetitive calculations. Moreover, the model is built under the assumption of particularly defined criteria completely meet the objectives of company.

In the future studies, the model can be extended to include other main processes of the companies so that the performance evaluation of the company can be fully performed. The evaluation results of the model can be compared in a time horizon in order to see the progress to achieve the company's objectives. The real time integration of the model with a database provides instant tracking of the company's performance scores. Another future study may be conducted to include other case studies from different sectors to provide the flexibility of the model in to other industries. Increasing the number of SMEs in the service sector obliges them to improve their services (Gazem et al., 2017). The proposed model can be applied in service sectors such as banking, healthcare, and education by using appropriate criteria. 


\section{REFERENCES}

Andersen, H., Lawrie, G., \& Shulver, M. (2000). The Balanced Scorecard vs. the EFQM Business Excellence Model-which is the better strategic management tool. 2GC Active Management. MPowerAisa. Retrieved from http://www.mpowerasia.com/pdf/BSC vs BEM.pdf

Bititci, U. S. (1996). Modelling of performance measurement systems in manufacturing enterprises. International Journal of Production Economics, 42(2), 137-147. doi:10.1016/0925-5273(95)00172-7

Bititci, U. S., Carrie, A. S., \& McDevitt, L. (1997). Integrated performance measurement systems: A development guide. International Journal of Operations \& Production Management, 17(5), 522-534. Retrieved from http:// www.emeraldinsight.com/journals.htm?articleid=849047\&show=abstract doi:10.1108/01443579710167230

Canvar Kahveci, T. (2007). The Institutionalization and the Enterprise Modeling in the Manufacturing Firms [Ph.D. Thesis]. Sakarya University.

Chalmeta, R., Palomero, S., \& Matilla, M. (2012). Methodology to develop a performance measurement system in small and medium-sized enterprises. International Journal of Computer Integrated Manufacturing, 25(8), 716-740. doi:10.1080/0951192X.2012.665178

Chang, D.-Y. (1996). Applications of the extent analysis method on fuzzy AHP. European Journal of Operational Research, 95(3), 649-655. doi:10.1016/0377-2217(95)00300-2

Chennell, A. F., Dransfield, S., Field, J. B., Fisher, N. I., Saunders, I. W., \& Shaw, D. E. (2000). OPM: A system for organisational performance measurement. In Performance Measurement - Past, Present and Future. Cambridge.

Cross, K. F., \& Lynch, R. L. (1988). The "SMART" way to define and sustain success. National Productivity Review, 8(1), 23-33. doi:10.1002/npr.4040080105

Gabus, A., \& Fontela, E. (1972). World problems, an invitation to further thought within the framework of DEMATEL. Geneva, Switzerland: Battelle Geneva Research Center.

Gabus, A., \& Fontela, E. (1973). Perceptions of the world problematique: Communication procedure, communicating with those bearing collective responsibility. Geneva, Switzerland: Battelle Geneva Research Centre.

Garengo, P., Biazzo, S., \& Bititci, U. S. (2005). Performance measurement systems in SMEs: A review for a research agenda. International Journal of Management Reviews, 7(1), 25-47. doi:10.1111/j.14682370.2005.00105.x

Genaidy, A., \& Karwowski, W. (2007). The Manufacturing Enterprise Diagnostic Instrument: A Tool for Assessment of Enterprise System Manufacturers. Human Factors and Ergonomics in Manufacturing, 16(1), 61-81. doi:10.1002/hfm

Ghalayini, A. M., Noble, J. S., \& Crowe, T. J. (1997). An integrated dynamic performance measurement system for improving manufacturing competitiveness. International Journal of Production Economics, 48(3), $207-225$. doi:10.1016/S0925-5273(96)00093-X

Gin Chong, H. (2008). Measuring performance of small-and-medium sized enterprises: The grounded theory approach. Journal of Business and Public Affairs, 2(1), 1-10.

Herman, E. (2011). The Impact Of The Industrial Sector On Romanian Employment. Journal of Knowledge Management, Economics and Information Technology, (6), 1-21.

Kanji, G. K. (2002). Performance measurement system. Total Quality Management, 13(5), 715-728. doi:10.1080/0954412022000002090

Kaplan, R. S., \& Norton, D. P. (1996). Using the Balanced Scorecard as a Strategic Management System. Harvard Business Review, 1-14. doi:10.1016/S0840-4704(10)60668-0

Keegan, D. P., Eiler, R. G., \& Jones, C. R. (1989). Are your performance measures obsoletes? Management Accounting, 70, 45-50.

Laitinen, E. K. (2002). A dynamic performance measurement system: Evidence from small Finnish technology companies. Scandinavian Journal of Management, 18(1), 65-99. doi:10.1016/S0956-5221(00)00021-X 
Lee, Y., Ryu, S.-Y., \& McKone-Sweet, K. E. (2013). The Role of Complementary Resources in the Development of E-Supply Chains and the Firm's Performance: An Exploratory Analysis of Secondary Data. International Journal of Operations Research and Information Systems, 4(2), 1-21. doi:10.4018/joris.2013040101

Lin, C. J., \& Wu, W. W. (2008). A causal analytical method for group decision-making under fuzzy environment. Expert Systems with Applications, 34(1), 205-213. doi:10.1016/j.eswa.2006.08.012

Malcolm Baldrige Performance Excellence Program. (n.d.). Retrieved from http://www.baldrigepe.org/

Neely, A., Adams, C., \& Kennerley, M. (2002). The Performance Prism: the Scorecard for Measuring and Managing Stakeholder Relationship. London, UK: Prentice Hall.

Nguyen, T. H. L. (2010). The usefulness of a Self-assessment approach based on o business excellence model. Newcastle Business School.

Opricovic, S., \& Tzeng, G.-H. (2003). Defuzzification Within a Multicriteria Decision Model. International Journal of Uncertainty, Fuzziness and Knowledge-based Systems, 11(5), 635-652. doi:10.1142/S0218488503002387

Ross, T. J. (2004). Fuzzy Logic with Engineering Applications (2nd ed.). Wiley.

Saaty, T. L. (1996). Decision making with dependence and feedback: The analytic network process. Pittsburgh: RWS Publications.

Striteska, M., \& Spickova, M. (2012). Review and Comparison of Performance Measurement Systems. The Journal of Organizational Management Studies, 2012, 1-13. doi:10.5171/2012.114900

Susilawati, A., Tan, J., Bell, D., \& Sarwar, M. (2013). Develop a Framework of Performance Measurement and Improvement System for Lean Manufacturing Activity. International Journal of Lean Thinking, 4(1), 51-64.

Suwignjo, P., Bititci, U., \& Carrie, A. S. (2000). Quantitative models for performance measurement system. International Journal of Production Economics, 64(1-3), 231-241. doi:10.1016/S0925-5273(99)00061-4

Taticchi, P., Balachandran, K. R., Botarelli, M., \& Cagnazzo, L. (2008). Performance Measurement Management for Small and Medium Enterprises: An Integrated Approach. Journal of Applied Management Accounting Research, 6(2), 57-72.

The EFQM Excellence Model. (n.d.). Retrieved from http://www.efqm.org/the-efqm-excellence-model

Walden, C. T. (2007). A taxonomy based assessment methodology for small and medium size manufacturers. Mississippi State University.

Yadav, N., \& Sagar, M. (2013). Performance measurement and management frameworks. Business Process Management Journal, 19(6), 947-971. doi:10.1108/BPMJ-01-2013-0003

Merve Cengiz Toklu is an Assistant Professor in the department of Industrial Engineering, Sakarya University, Sakarya, Turkey. She received the M.Sc. and the PhD. degree in Industrial Engineering from the Sakarya University in 2010 and 2016, respectively. Her main areas of research interest are performance management, strategic management, multi criteria decision making approaches and fuzzy logic. She had worked as a production planning consultant in a manufacturing SME for four years. She has been working in Sakarya University since 2011.

Harun Taşkın is a Professor in the department of Industrial Engineering, Sakarya University, Sakarya, Turkey. He received his MBA degree in faculty of Business Administration, department of Production Management from Istanbul University, Istanbul, Turkey in 1979. He received his PhD degree in the department of Management Engineering from Istanbul Technical University, Istanbul, Turkey in 1984. His main areas of research interest are fuzzy systems, manufacturing systems engineering, and philosophy of technology. 